\title{
THE INHERITANCE OF THE MNS BLOOD GROUPS : A SECOND SERIES OF FAMILIES
}

R. R. RACE, RUTH SANGER, SYLVIA D. LAWLER and DOREEN BERTINSHAW

Medical Research Council, Blood Group Research Unit, Lister Institute, London, S.W.I

Received 15. ii. 49

While examining human sera for $\mathrm{Rh}$ antibodies Walsh and Montgomery (1947) found an agglutinin which did not apparently correspond to any of the known blood-group antigens. Sanger and Race (I 947) showed that this agglutinin subdivided the three groups of the MN system in such a way that connection between the new antigen, which they called $\mathrm{S}$, and the $\mathrm{MN}$ antigens must exist. By statistical analysis of the results of tests on unrelated persons, and by family investigations, they were able to show that the MNS system of blood groups depended either on two pairs of very closely linked genes MS, Ms, NS and Ns, or on four allelomorphs at the MN locus.

A second example of anti-S was soon found (Pickles, 1948), and subsequently several have been recognised; no example of anti-s has yet been identified, though by analogy with the Rh system there is every reason to anticipate that it will be found.

The MNS blood groups of only 30 families have so far been published (Sanger, Race, Walsh and Montgomery, 1948). The results of testing a further 93 English families for these groups are here presented, and the total of 123 families is examined statistically. The MNS groups of the 93 families are given in table I. The families were all tested for other blood groups but the addition of these results would confuse the table. Twins are bracketed: when a pair was not shown to be dizygous, by sex or by any of the 6 blood groups for which these families were tested, they have been marked monozygous and scored in the calculations as one child. The high incidence of identical twins in this series of families is due to selection ; 3 of the 4 pairs were sent to us because they were twins thought to be identical.

In table I the numbers in the column headed "type of mating" refer to the catalogue of matings given in table I of a previous paper (Sanger, Race, Walsh and Montgomery, 1948). In this earlier paper a blood sample which was not agglutinated by the anti-S serum was called for example, MN. As this did not indicate that the blood had been tested with the anti-S serum we now call it MsNs. In the first paper we indicated the phenotype $\mathrm{MM}$ anti-S positive, which might be of the genotype MS MS or MS Ms, thus (MM)S ; we have now removed the brackets and have made use of a full stop, thus MM.S. 
TABLE I

The MNS groups of 93 families

\begin{tabular}{|c|c|c|c|c|c|c|c|c|c|}
\hline \multirow{2}{*}{ No. } & \multirow{2}{*}{$\begin{array}{l}\text { Type of } \\
\text { mating }\end{array}$} & \multicolumn{2}{|c|}{ Parents } & \multicolumn{6}{|c|}{ Children } \\
\hline & & Father & Mother & I & 2 & 3 & 4 & 5 & 6 \\
\hline $\begin{array}{l}31 \\
32 \\
33 \\
34 \\
35 \\
36 \\
37 \\
38 \\
39\end{array}$ & $\begin{array}{l}2 b \\
2 \\
3 \\
3 \\
3 \\
3 \\
4 a \\
4 a \\
4 a\end{array}$ & $\begin{array}{l}\text { MSMs } \\
\text { MM.S } \\
\text { MM.S } \\
\text { MM.S } \\
\text { MM.S } \\
\text { MM.S } \\
\text { MsMs } \\
\text { MsNs } \\
\text { MsNs }\end{array}$ & $\begin{array}{l}\text { MsMs } \\
\text { MsMs } \\
\text { MM.S } \\
\text { MM.S } \\
\text { MM.S } \\
\text { MM.S } \\
\text { MsNs } \\
\text { MsMs } \\
\text { MsMs }\end{array}$ & $\begin{array}{l}\text { MsMs } \\
\text { MSMs } \\
\text { MM.S } \\
\text { MM.S } \\
\text { MM.S } \\
\text { MM.S } \\
\text { MsNs } \\
\text { MsMs } \\
\text { MsNs }\end{array}$ & $\begin{array}{l}\text { MSMs } \\
\text { MSMs } \\
\text { MM.S } \\
\text { MM.S } \\
\text { MsNs }\end{array}$ & $\begin{array}{l}\text { MSMs } \\
\text { MM.S } \\
\text { MM.S }\end{array}$ & & & \\
\hline $\begin{array}{l}40 \\
41\end{array}$ & $\begin{array}{l}4 a \\
4 a\end{array}$ & $\begin{array}{l}\text { MsMs } \\
\text { MsMs }\end{array}$ & $\begin{array}{l}\text { MsNs } \\
\text { MsNs }\end{array}$ & $\begin{array}{l}\text { MsMs } \\
\text { MsNs }\end{array}$ & $\begin{array}{l}\text { MsMs * } \\
\text { MsMs }\end{array}$ & MsNs & MsMs & & \\
\hline $\begin{array}{l}42 \\
43 \\
44 \\
45\end{array}$ & $\begin{array}{l}5^{b} \\
5^{b} \\
5^{b} \\
5\end{array}$ & $\begin{array}{l}\text { MsNs } \\
\text { MSMs } \\
\text { MsNs } \\
\text { MM.S }\end{array}$ & $\begin{array}{l}\text { MSMs } \\
\text { MsNs } \\
\text { MSMs } \\
\text { MsNs }\end{array}$ & $\begin{array}{l}\text { MSNs } \\
\text { MsNs } \\
\text { MsMs } \\
\text { MSMs }\end{array}$ & $\begin{array}{l}\text { MsMs } \\
\text { MSNs } \\
\text { MSNs } \\
\text { MSMs }\end{array}$ & $\begin{array}{l}\text { MsMs } \\
\text { MSMs } \\
\text { MSNs }\end{array}$ & MSNs & MSNs & MSNs \\
\hline $\begin{array}{l}46 \\
47\end{array}$ & $\begin{array}{l}5 \\
5\end{array}$ & $\begin{array}{l}\text { MsNs } \\
\text { MM.S }\end{array}$ & $\begin{array}{l}\text { MM.S S } \\
\text { MsNs }\end{array}$ & $\begin{array}{l}\text { MSMs } \\
\text { MSMs }\end{array}$ & $\begin{array}{l}\text { MSMs } \\
\text { MSMs }\end{array}$ & MSMs * & & & \\
\hline $\begin{array}{l}48 \\
49 \\
50 \\
5^{1}\end{array}$ & $\begin{array}{l}5 \\
5 \\
5 \\
6 b\end{array}$ & $\begin{array}{l}\text { MsNs } \\
\text { MsNs } \\
\text { MsNs } \\
\text { MsMs }\end{array}$ & $\begin{array}{l}\text { MM.S } \\
\text { MM.S } \\
\text { MM.S } \\
\text { MSNs }\end{array}$ & $\begin{array}{l}\text { MSMs } \\
\text { MSNs } \\
\text { MSMs } \\
\text { MSMs }\end{array}$ & $\begin{array}{l}\text { MSMs * } \\
\text { MSMs } \\
\text { MsNs }\end{array}$ & MSMs & MsNs & & \\
\hline $\begin{array}{l}52 \\
53 \\
54 \\
55 \\
56 \\
57 \\
58 \\
59 \\
60 \\
61 \\
62\end{array}$ & $\begin{array}{l}6 b \\
7 e \\
7 e \\
7 f \\
7 \\
7 \\
7 \\
7 \\
7 \\
7 \\
7\end{array}$ & $\begin{array}{l}\text { MsMs } \\
\text { MSNs } \\
\text { MSNs } \\
\text { MsNS } \\
\text { MM.S } \\
\text { MM.S } \\
\text { MM.S } \\
\text { MN.S } \\
\text { MM.S } \\
\text { MM.S } \\
\text { MM.S }\end{array}$ & $\begin{array}{l}\text { MSNs } \\
\text { MSMs } \\
\text { MSMs } \\
\text { MSMs } \\
\text { MN.S } \\
\text { MN.S } \\
\text { MM.S } \\
\text { MN.S } \\
\text { MN.S } \\
\text { MN.S }\end{array}$ & $\begin{array}{l}\text { MSMs } \\
\text { MM.S } \\
\text { MM.S } \\
\text { MsMs } \\
\text { MM.S } \\
\text { MM.S } \\
\text { MM.S } \\
\text { MN.S } \\
\text { MN.S } \\
\text { MM.S } \\
\text { MN.S }\end{array}$ & $\begin{array}{l}\text { MSMs } \\
\text { MSNs } \\
\text { MsNs } \\
\text { MN.S } \\
\text { MN.S } \\
\text { MM.S } \\
\text { MM.S } \\
\text { MN.S } \\
\text { MM.S }\end{array}$ & MN.S & MSMs & & \\
\hline $\begin{array}{l}63 \\
64 \\
65 \\
66 \\
67 \\
68 \\
69 \\
70 \\
71 \\
72 \\
73 \\
74\end{array}$ & $\begin{array}{l}7 \\
7 \\
7 \\
8 a \\
8 a \\
8 a \\
8 a \\
9^{b} \\
9^{b} \\
9^{b} \\
9 \\
10\end{array}$ & $\begin{array}{l}\text { MN.S } \\
\text { MM.S } \\
\text { MM.S } \\
\text { NsNs } \\
\text { NsNs } \\
\text { NsNs } \\
\text { MsMs } \\
\text { MSMs } \\
\text { MSMs } \\
\text { NsNs } \\
\text { NsNs } \\
\text { NN.S }\end{array}$ & $\begin{array}{l}\text { MM.S } \\
\text { MN.S } \\
\text { MN.S } \\
\text { MsMs } \\
\text { MsMs } \\
\text { MsMs } \\
\text { NsNs } \\
\text { NsNs } \\
\text { NsNs } \\
\text { MSMs } \\
\text { MM.S } \\
\text { MsMs }\end{array}$ & $\begin{array}{l}\text { MN.S } \\
\text { MM.S } \\
\text { MM.S } \\
\text { MsNs } \\
\text { MsNs } \\
\text { MsNs } \\
\text { MsNs } \\
\text { MsNs } \\
\text { MSNs } \\
\text { MSNs } \\
\text { MSNs } \\
\text { MsNS }\end{array}$ & $\begin{array}{l}\text { MM.S } \\
\text { MM.S } \\
\text { MM.S } \\
\text { MsNs } \\
\text { MsNs } \\
\text { MsNs } \\
\\
\text { MsNs } \\
\text { MsNs } \\
\text { MsNs }\end{array}$ & $\begin{array}{l}\text { MN.S } \\
\text { MsNs } \\
\text { MsNs }\end{array}$ & MsNs & MsNs & MsNs \\
\hline
\end{tabular}


TABLE I-continued

\begin{tabular}{|c|c|c|c|c|c|c|c|c|c|}
\hline \multirow{2}{*}{ No. } & \multirow{2}{*}{$\begin{array}{l}\text { Type of } \\
\text { mating }\end{array}$} & \multicolumn{2}{|c|}{ Parents } & \multicolumn{6}{|c|}{ Children } \\
\hline & & Father & Mother & I & 2 & 3 & 4 & 5 & 6 \\
\hline $\begin{array}{l}75 \\
76\end{array}$ & $\begin{array}{l}\text { II } d \\
\text { II }\end{array}$ & $\begin{array}{l}\text { NSNs } \\
\text { MM.S }\end{array}$ & $\begin{array}{l}\text { MSMs } \\
\text { NN.S }\end{array}$ & $\begin{array}{l}\text { MsNs } \\
\text { MN.S }\end{array}$ & MN.S & & & & \\
\hline 77 & II & NN.S & MM.S & MN.S & MN.S * & & & & \\
\hline 78 & $12 a$ & MsNs & MsNs & $\mathrm{MsNs}$ & MsNs & & & & \\
\hline 79 & $12 a$ & MsNs & MsNs & $\mathrm{MsNs}$ & MsMs & NsNs & & & \\
\hline 80 & $12 a$ & MsNs & MsNs & NsNs & & & & & \\
\hline 81 & $12 a$ & MsNs & $\mathrm{MsNs}$ & $\mathrm{MsNs}$ & NsNs & & & & \\
\hline $\begin{array}{l}82 \\
83\end{array}$ & $\begin{array}{l}13 b \\
13 b\end{array}$ & $\begin{array}{l}\text { MSNs } \\
\text { MsNs }\end{array}$ & $\begin{array}{l}\text { MsNs } \\
\text { MSNs }\end{array}$ & $\begin{array}{l}\text { MSNs } \\
\text { NsNs }\end{array}$ & $\begin{array}{l}\text { NsNs } \\
\text { MSNs }\end{array}$ & MsNs & & & \\
\hline 84 & $13 b$ & $\mathrm{MsNs}$ & MSNs & MSMs & MSNs & NsNs & & & \\
\hline 85 & $13^{b}$ & MSNs & MsNs & NsNs & MSNs & MSMs & & & \\
\hline 86 & $13^{b}$ & MsNs & MSNs & MSMs & MsNs & MSNs & & & \\
\hline 87 & $13^{b}$ & MSNs & MsNs & NsNs & MSNs & MSNs & & & \\
\hline 88 & $13^{b}$ & MSNs & MsNs & NsNs & & & & & \\
\hline 89 & ${ }^{1} 3^{b}$ & MsNs & MSNs & MSNs & MsNs & MsNs & MSMs & NsNs & \\
\hline 90 & $13^{c}$ & MsNs & MsNS & MsMs & & & & & \\
\hline 91 & 13 not $a$ & MsNs & MN.S & MN.S & MsNs & MN.S & & & \\
\hline 92 & I 3 not $b$ & MsNs & MN.S & NSNs & & & & & \\
\hline 93 & 13 not $c$ & MsNs & MN.S & MSMs & MN.S & & & & \\
\hline 94 & 13 & MN.S & MsNs & MN.S & & & & & \\
\hline 95 & 13 & MN.S & MsNs & MN.S & & & & & \\
\hline 96 & $14 d$ & MSNs & MSNs & NsNs & MSNs & & & & \\
\hline 97 & $14 d$ & MSNs & MSNs & MSMS & MSNs & $\mathrm{NsNs}$ & MSMS & MSNs & \\
\hline 98 & $14 d$ & MSNs & MSNs & MSMS & MSMS & NsNs & & & \\
\hline 99 & $14 e$ & MN.S & MN.S & MN.S & NSNs & MsNs & NSNs & & \\
\hline 100 & 14 not $f$ & MN.S & MN.S & MN.S & MM.S & & & & \\
\hline 101 & 14 & MN.S & MN.S & MN.S & MN.S & & & & \\
\hline 102 & 14 & MN.S & MN.S & MN.S & MN.S & & & & \\
\hline 103 & $15^{a}$ & NsNs & MsNs & NsNs & & & & & \\
\hline 104 & I $6 b$ & $\begin{array}{l}\text { MSNs } \\
\text { NsNs }\end{array}$ & $\begin{array}{l}\text { NsNs } \\
\text { MSNs }\end{array}$ & $\begin{array}{l}\text { MSNs } \\
\text { MSNs }\end{array}$ & $\begin{array}{l}\text { NsNs } \\
\text { NsNs }\end{array}$ & & & & \\
\hline $\begin{array}{l}105 \\
106\end{array}$ & $\begin{array}{l}16 b \\
16 b\end{array}$ & NsNs & $\begin{array}{l}\text { MSNs } \\
\text { MSNs }\end{array}$ & NsNs & $\begin{array}{l}\text { NsNs } \\
\text { NsNs }\end{array}$ & & & & \\
\hline 107 & $16 b$ & MSNs & NsNs & NsNs & & & & & \\
\hline 108 & $16 b$ & NsNs & MSNs & MSNs & NsNs & NsNs & & & \\
\hline 109 & $16 c$ & MsNS & NsNs & MsNs & MsNs & NSNs & & & \\
\hline IIo & 16 not $b$ & NsNs & MN.S & NSNs & & & & & \\
\hline III & I 6 not $b$ & MN.S & NsNs & NSNs & NSNs & & & & \\
\hline 112 & I 6 not $c$ & NsNs & MN.S & MSNs & MSNs & MSNs & & & \\
\hline 113 & $17 d$ & NSNs & MSNs & MN.S & NsNs & & & & \\
\hline 114 & 17 & NN.S & MN.S & MN.S & NN.S & MN.S & NN.S & & \\
\hline 115 & 17 & MN.S & NN.S & MN.S & MN.S & & & & \\
\hline 116 & $18 b$ & MsNs & NSNs & MsNs & NsNs & NSNs & & & \\
\hline 117 & 18 & NN.S & MsNs & MsNS & & & & & \\
\hline 118 & 18 & NN.S & MsNs & $\begin{array}{l}\text { MsNS } \\
\text { NsNs }\end{array}$ & NsNs & NsNs & & & \\
\hline 119 & $\begin{array}{l}19 a \\
21 b\end{array}$ & $\begin{array}{l}\text { NsNs } \\
\text { NsNs }\end{array}$ & $\begin{array}{l}\text { NsNs } \\
\text { NSNs }\end{array}$ & $\begin{array}{l}\text { NsNs } \\
\text { NsNs }\end{array}$ & NASINS & IVSIVS & & & \\
\hline $\begin{array}{l}120 \\
121\end{array}$ & $2 \mathrm{I} b$ & NSNs & NsNs & NSNs & NsNs & NsNs & & & \\
\hline 122 & $2 \mathrm{I} b$ & NSNs & NsNs & NsNs & & & & & \\
\hline 123 & 21 & NN.S & NsNs & NSNs & NSNs & NSNs & & & \\
\hline
\end{tabular}

MN.S written thus indicates that the $\mathrm{S}$ gene may be located on either or both the chromosomes. When family grouping makes clear the position of the $\mathrm{S}$, it is written thus, MSNs or MsNS or MSNS.

$$
\text { * = monozygous twins. }
$$


The gene frequencies which form the basis of the calculations to follow are those derived by Fisher from the results of tests with anti-M, anti-N and anti-S sera on the red cells of 580 unrelated persons (Walsh and Montgomery, 1947 ; Sanger and Race, 1947 ; Pickles, 1948). They are (Pickles, I948) :-

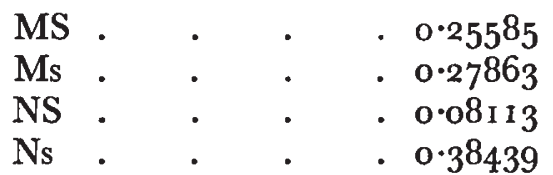

The expected incidence of the 123 families in the 21 phenotypically distinct mating groups can be calculated from these gene frequencies. The expected distribution, and that actually observed, is shown in table 2 ; it will be seen that the agreement between the two sets of figures is close.

TABLE 2

The expected and the observed distribution of the 123 families in the 21 phenotypically distinct mating types

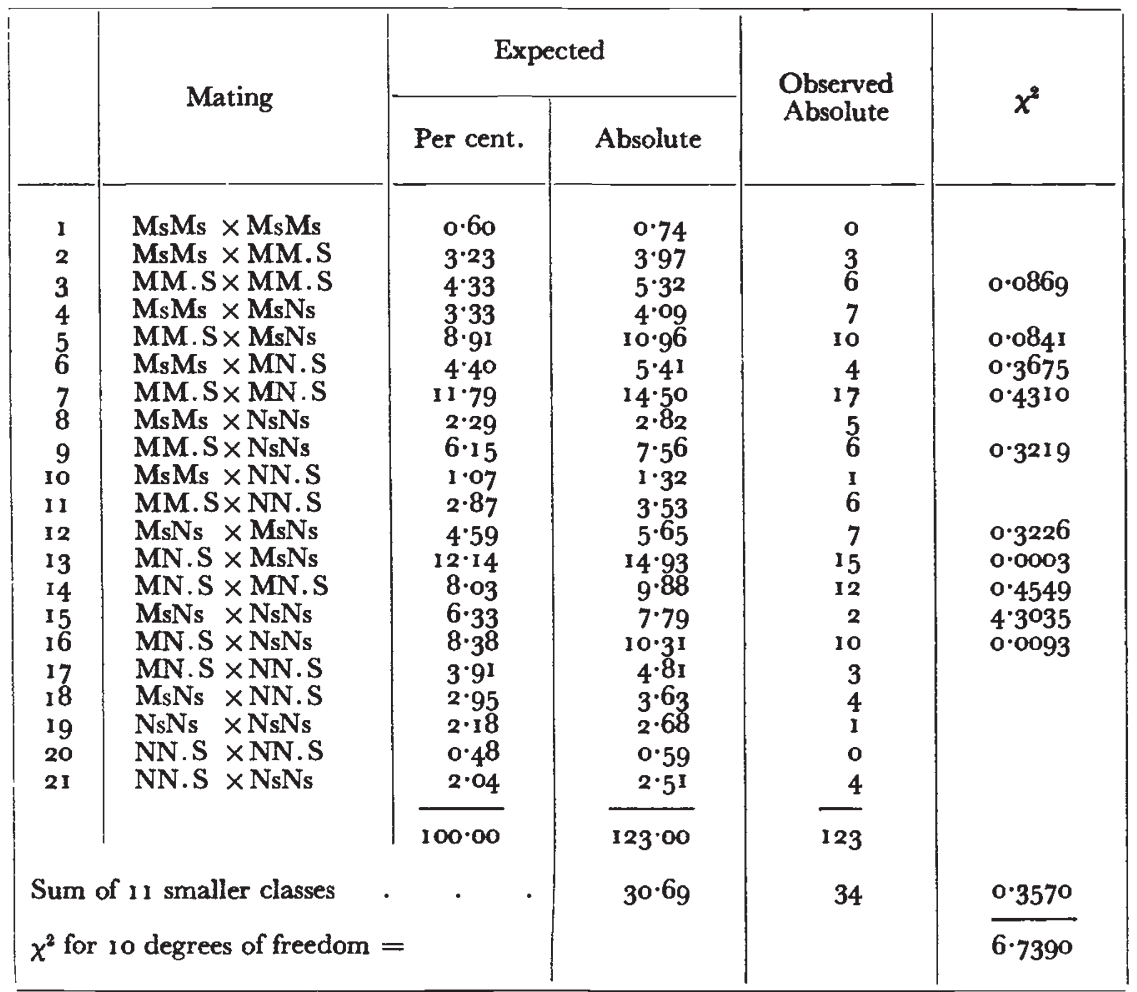

Probability between 0.8 and 0.7 .

In the first place we propose to confine our analysis to the $\mathrm{S}$ gene and its allelomorph s. At present $\mathrm{s}$ cannot be recognised in a positive 
way for no anti-s serum has yet been found. The position of the gene $\mathrm{s}$ is that which was, until recently, held by the $R h$ genes $e$ and $d$, and the antigen $s$ may be considered for the time being as a recessive character only recognisable as an absence of $\mathrm{S}$. We cannot say whether a person belongs to the group SS or Ss without the knowledge of the groups of other members of his family, for both types of red cell are agglutinated by the anti-S serum, and so far we have not observed any clear dosage effect which would distinguish the two types of blood.

From the gene frequencies given above we may, by addition, obtain the following frequencies for $S$ and $s$.

$$
\begin{aligned}
& S=0.33698 \\
& s=0.66302
\end{aligned}
$$

and the frequencies of the three genotypes will be

$$
\begin{aligned}
& \mathrm{SS}=0.1 \mathrm{I} 35^{6} \\
& \mathrm{Ss}=0.44685 \\
& \mathrm{sS}=0.43960
\end{aligned}
$$

From these may be derived the expected frequencies of the various types of mating and of the issue expected therefrom. These are given

\begin{tabular}{|c|c|c|c|c|c|c|}
\hline \multicolumn{4}{|c|}{ Mating } & \multicolumn{3}{|c|}{ Children } \\
\hline \multicolumn{3}{|c|}{ Type } & Frequency & SS & Ss & ss \\
\hline $\begin{array}{l}\mathrm{SS} \times \mathrm{SS} \\
\mathrm{SS} \times \mathrm{Ss} \\
\mathrm{Ss} \times \mathrm{Ss} \\
\mathrm{SS} \times \text { ss } \\
\mathrm{Ss} \times \text { ss } \\
\text { ss } \times \text { ss }\end{array}$ & : & $\begin{array}{l}\dot{.} \\
\dot{5} \\
\dot{.}\end{array}$ & $\begin{array}{l}0 \cdot 0129 \\
0 \cdot 1015 \\
0 \cdot 1997 \\
0 \cdot 0999 \\
0 \cdot 3929 \\
0 \cdot 1932\end{array}$ & $\begin{array}{c}0.0129 \\
0.05075 \\
0.04992 \\
\ldots \\
\ldots \\
\ldots\end{array}$ & $\begin{array}{c}\ldots \\
0.05075 \\
0.09985 \\
0.0999 \\
0.19645 \\
\quad \ldots\end{array}$ & $\begin{array}{c}\ldots \\
\ldots \\
0 \cdot 04992 \\
\ldots \\
0 \cdot 19645 \\
0 \cdot 193^{2}\end{array}$ \\
\hline & & & $1 \cdot 0001$ & $0 \cdot 11357$ & 0.44695 & 0.43957 \\
\hline
\end{tabular}
in table 3 .

TABLE 3

The expected frequencies of the various types of $S$ mating and the issue expected therefrom

The figures in table 3 have been used to calculate the expected incidence in the three phenotypically distinguishable mating types of the 123 pairs of parents, together with the expected distribution of the $\mathrm{S}$ groups in their 293 children. These expectations are given in table 4, where they are compared with the observed numbers; once again the agreement is close.

Such an analysis shows that the $\mathbf{S}$ antigen is inherited as a dominant character, it does not disclose the very close relationship between the Ss genes and the MN genes. 
Sanger and Race (1947) demonstrated that the antigen $S$ depended on a gene $\mathrm{S}$, with presumably, an allelomorph $\mathrm{s}$, and that these genes were either part of the MN genes or, more probably, very closely linked to the MN genes. The linkage is so close that no crossing over

TABLE 4

The $S$ groups of 123 families with 293 children

\begin{tabular}{|c|c|c|c|c|c|c|c|c|}
\hline \multicolumn{3}{|c|}{ Mating } & \multicolumn{6}{|c|}{ Children } \\
\hline \multirow{2}{*}{ Type } & \multicolumn{2}{|c|}{ Number } & \multirow{2}{*}{ Number } & \multicolumn{2}{|c|}{$\mathbf{S}$} & \multicolumn{2}{|c|}{ ss } & \multirow{2}{*}{$\begin{array}{l}\chi^{2} \text { for } \\
\text { I d.f. }\end{array}$} \\
\hline & Expected & Observed & & Expected & Observed & Expected & Observed & \\
\hline \multirow[t]{2}{*}{$\begin{array}{l}\mathbf{S} \times \mathbf{S} \\
\mathbf{S} \times s \mathrm{sS} \\
\mathrm{ss} \times \mathrm{ss}\end{array}$} & $\begin{array}{l}38 \cdot 6 \\
60 \cdot 6 \\
23 \cdot 8\end{array}$ & $\begin{array}{l}44 \\
57 \\
22\end{array}$ & $\begin{array}{r}104 \\
136 \\
53\end{array}$ & \multirow[t]{2}{*}{$\begin{array}{r}87.5 \\
8 \mathrm{r} \cdot 8 \\
0.0\end{array}$} & \multirow[t]{2}{*}{$\begin{array}{r}92 \\
84 \\
0\end{array}$} & \multirow[t]{2}{*}{$\begin{array}{l}16 \cdot 5 \\
54 \cdot 2 \\
53 \cdot 0\end{array}$} & \multirow[t]{2}{*}{$\begin{array}{l}12 \\
52 \\
53\end{array}$} & \multirow[t]{2}{*}{$\begin{array}{c}\mathrm{I} \cdot 46 \\
0 \cdot 15 \\
\ldots\end{array}$} \\
\hline & 123.0 & 123 & 293 & & & & & \\
\hline
\end{tabular}

has been observed in those of the 123 families capable of disclosing it : that is families of at least 2 children, shown by one of the children to be of the mating types $6 b$ or $c, 7 e$ or $f, \mathrm{1} 3 b$ or $c, 14 d, e$ or $f, 16 b$ or $c$ or $17 d$ or $f$. The children in these relevant families number 82 . Nor was crossing over expected in such a small sample, for if crossing over occurs at all freely the ratio of MS : Ms genes would be expected to equal that of NS : Ns which is not the case. The situation is very like that found in the Rh system, and will be exactly so when an anti-s antibody is found; such an antibody will agglutinate the blood of about 89 per cent. of Englishmen.

A more complex analysis of the 123 families is given in table 5 which shows the expected and the observed incidence of the 293 children in the 6 phenotype groups. Taking into account the small numbers of children from some of the mating types there is seen to be good agreement between the observed and expected numbers.

It will be seen from table 2 that 19 of the possible 21 phenotypically different matings are represented. The I23 families demonstrate unequivocally 21 of the 55 genotypically different matings shown in table $\mathrm{I}$ of the earlier paper.

Family No. 89 (fig. I) may be taken as an example of the effect of the anti-S serum on the MN blood groups. Without the information given by the anti-S serum it could only have been said that child 4 had received a paternal and maternal $M$ gene, and child 5 a paternal and maternal $\mathrm{N}$ gene. The origin of each of the genes of the first 3 children was ambiguous, it might have been paternal or maternal. The anti-S serum, however, makes clear the origin of all the genes of these three children. 
The anti-S serum will contribute greatly to the usefulness of the MN blood groups as markers for linkage owing to the increased number of recognisable heterozygotes.

TABLE 5

Showing the expected and the observed incidence of children in the 6 phenotype groups

\begin{tabular}{|c|c|c|c|c|c|c|c|c|c|c|c|c|c|c|}
\hline & \multirow{3}{*}{ Mating } & \multicolumn{13}{|c|}{ Children } \\
\hline & & \multirow{2}{*}{ Total } & \multicolumn{2}{|c|}{ MsMs } & \multicolumn{2}{|c|}{ MM.S } & \multicolumn{2}{|c|}{$\mathrm{MsNs}$} & \multicolumn{2}{|c|}{ MN.S } & \multicolumn{2}{|c|}{ NsNs } & \multicolumn{2}{|c|}{ NN.S } \\
\hline & & & Exp. & Ob. & Exp. & Ob. & Exp. & Ob. & Exp. & Ob. & Exp. & Ob. & Exp. & Ob. \\
\hline \multirow{21}{*}{$\begin{array}{r}1 \\
2 \\
3 \\
4 \\
5 \\
6 \\
7 \\
8 \\
9 \\
10 \\
11 \\
12 \\
13 \\
14 \\
15 \\
16 \\
17 \\
18 \\
19 \\
20 \\
21\end{array}$} & \multirow{21}{*}{$\begin{array}{l}\text { MsMs } \times \text { MsMs } \\
\text { MsMs } \times \text { MM.S } \\
\text { MM.S } \times \text { MM.S } \\
\text { MsMs } \times \text { MsNs } \\
\text { MM.S } \times \text { MsNs } \\
\text { MsMs } \times \text { MN.S } \\
\text { MM.S } \times \text { MN.S } \\
\text { MsMs } \times \text { NsNs } \\
\text { MM.S } \times \text { NsNs } \\
\text { MsMs } \times \text { NN.S } \\
\text { MM.S } \times \text { NN.S } \\
\text { MsNs } \times \text { MsNs } \\
\text { MN.S } \times \text { MsNs } \\
\text { MN.S } \times \text { MN.S } \\
\text { MsNs } \times \mathrm{NsNs} \\
\text { MN.S } \times \mathrm{NsNs} \\
\text { MN.S } \times \text { NN.S } \\
\text { MsNs } \times \mathrm{NN} . S \\
\text { NsNs } \times \mathrm{NsNs} \\
\mathrm{NN} . S \times \mathrm{NN} . S \\
\mathrm{NN} . \mathrm{S} \times \mathrm{NsNs}\end{array}$} & 0 & 0.00 & $o$ & & $\ldots$ & & & & & & & & \\
\hline & & 8 & $2 \cdot 74$ & $I$ & $5 \cdot 26$ & $\dddot{7}$ & $\ldots$ & $\ldots$ & $\ldots$ & $\ldots$ & $\ldots$ & $\ldots$ & $\ldots$ & $\ldots$ \\
\hline & & 15 & $1 \cdot 76$ & $o$ & 13.24 & $r 5$ & & $\ldots$ & $\ldots$ & $\ldots$ & $\ldots$ & $\ldots$ & $\ldots$ & $\ldots$ \\
\hline & & 16 & $8 \cdot 00$ & 7 & -1 & $\ldots$ & $8 \cdot 00$ & 9 & & $\ldots$ & $\ldots$ & $\ldots$ & $\ldots$ & $\ldots$ \\
\hline & & 25 & $4 \cdot 28$ & 3 & $8 \cdot 22$ & $I I$ & $4 \cdot 28$ & $r$ & $8 \cdot 22$ & ro & $\cdots$ & $\cdots$ & $\cdots$ & $\cdots$ \\
\hline & & 19 & $1 \cdot 5^{2}$ & $o$ & $7 \cdot 98$ & $r o$ & $6 \cdot 59$ & 9 & $2 \cdot 9^{\mathrm{I}}$ & $o$ & $\ldots$ & $\ldots$ & $\ldots$ & $\ldots$ \\
\hline & & 34 & 0.93 & $I$ & $16 \cdot 07$ & $2 I$ & 4.04 & 3 & $\mid 12 \cdot 96$ & 9 & $\ldots$ & $\ldots$ & $\ldots$ & $\ldots$ \\
\hline & & 13 & $\cdots$ & $\cdots$ & $\cdots$ & $\cdots$ & $13.00 \mid$ & 13 & & & $\cdots$ & $\cdots$ & $\cdots$ & $\cdots$ \\
\hline & & 12 & $\cdots$ & $\cdots$ & $\ldots$ & $\cdots$ & $4 \cdot{ }^{\prime I I}$ & 6 & $7 \cdot 89$ & 6 & $\ldots$ & $\ldots$ & $\ldots$ & $\ldots$ \\
\hline & & I & $\ldots$ & $\ldots$ & $\ldots$ & $\ldots$ & 0.45 & $o$ & 0.55 & $I$ & $\ldots$ & $\ldots$ & $\ldots$ & $\ldots$ \\
\hline & & 14 & $\cdots$ & $\cdots$ & $\cdots$ & $\cdots$ & $2 \cdot 17$ & 2 & II $\cdot 83$ & 12 & $\cdots$ & $\cdots$ & $\cdots$ & $\cdots$ \\
\hline & & 16 & $4^{\circ} 00$ & 2 & $\ldots$ & $\cdots$ & $8 \cdot 00$ & $I I$ & $\ldots$ & $\ldots$ & $4^{\circ} 00$ & 3 & $\cdots$ & $\cdots$ \\
\hline & & 35 & 1.40 & $r$ & $7 \cdot 35$ & 5 & 7.47 & 6 & 10.03 & 15 & $6 \cdot 07$ & 7 & $2 \cdot 68$ & $r$ \\
\hline & & 33 & 0.21 & $o$ & $8 \cdot 04$ & 8 & $1 \cdot 82$ & 2 & $14 \cdot 67$ & 16 & $3 \cdot 97$ & 3 & $4 \cdot 27$ & 4 \\
\hline & & 5 & $\cdots$ & $\cdots$ & $\cdots$ & $\cdots$ & $\begin{array}{r}2 \cdot 50 \\
7 \cdot 76\end{array}$ & 2 & $\ldots$ & $\dddot{\sigma}$ & $2 \cdot 50$ & 3 & $\cdots$ & $\cdots$ \\
\hline & & $\begin{array}{r}22 \\
8\end{array}$ & $\begin{array}{l}\cdots \\
\ldots\end{array}$ & $\begin{array}{l}\cdots \\
\cdots\end{array}$ & $\begin{array}{l}\cdots \\
\cdots\end{array}$ & $\begin{array}{l}\cdots \\
\cdots\end{array}$ & $\begin{array}{l}1 \cdot 76 \\
0 \cdot 29\end{array}$ & $\begin{array}{l}4 \\
0\end{array}$ & $\begin{array}{l}9 \cdot 24 \\
3 \cdot 7^{1}\end{array}$ & $\begin{array}{l}0 \\
5\end{array}$ & $\begin{array}{l}7 \cdot 63 \\
1 \cdot 26\end{array}$ & $\begin{array}{l}7 \\
r\end{array}$ & $\begin{array}{l}3.37 \\
2 \cdot 74\end{array}$ & $\begin{array}{l}5 \\
2\end{array}$ \\
\hline & & 6 & $\ldots$ & $\ldots$ & $\ldots$ & $\ldots$ & I-36 & 2 & $\begin{array}{l}1.64 \\
\end{array}$ & 2 & I-36 & $I$ & 1.64 & $I$ \\
\hline & & 3 & $\cdots$ & $\cdots$ & $\cdots$ & $\cdots$ & $\cdots$ & $\cdots$ & $\cdots$ & $\cdots$ & 3.00 & 3 & $\cdots$ & $\cdots$ \\
\hline & & ○ & $\cdots$ & $\cdots$ & $\cdots$ & $\cdots$ & $\cdots$ & $\cdots$ & $\cdots$ & $\cdots$ & 0.00 & $o$ & 0.00 & 0 \\
\hline & & 8 & $\cdots$ & $\cdots$ & $\cdots$ & $\cdots$ & $\cdots$ & $\cdots$ & $\cdots$ & $\cdots$ & $3 \cdot 62$ & 4 & $4 \cdot 38$ & 4 \\
\hline & & 293 & $24 \cdot 84$ & 15 & $66 \cdot{ }_{1} 6$ & 77 & $65 \cdot 84$ & 70 & $83 \cdot 65 \mid$ & 82 & $33 \cdot 4 \mathrm{I}$ & 32 & $19 \cdot 08$ & 17 \\
\hline
\end{tabular}

Total expected $292 \cdot 98$

Total observed 293

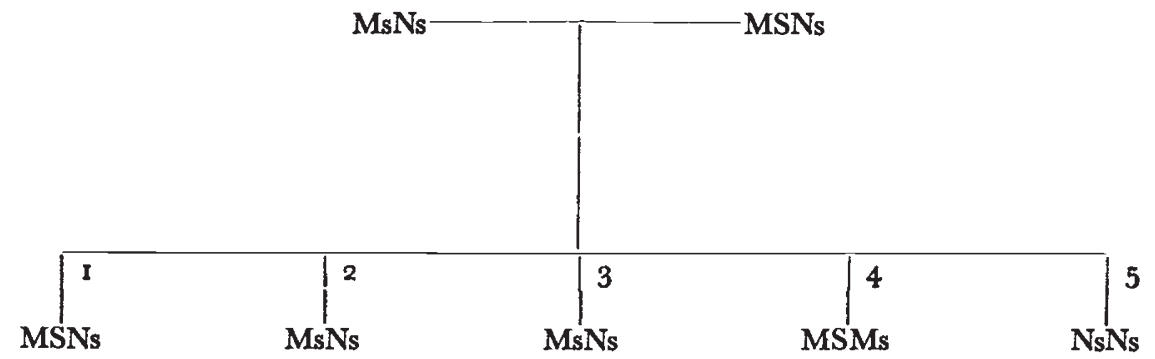

FIG. 1.-Family number 89 .

Professor Fisher has pointed out that the MNS system is now more efficient in making distinction between two human beings than the $A_{1} A_{2} B \quad O$ system and only slightly less so than the Rh system. This 
efficiency may be compared as follows : the sums of the squares of the phenotype frequencies represent the percentage of failures to distinguish between two random samples of English blood ; they are :-

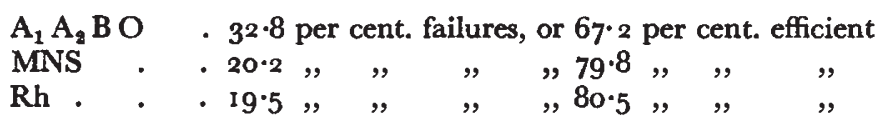

The proportion of failures to recognise (a) erronious parentage, or (b) erronious paternity, the mother being known, is of course larger, but the relation value of the three factors is much the same.

When the anti-s serum becomes available the MNS will be much the most useful, genetically, of all the systems so far known. The $A_{1} A_{2} B O$ calculations are based on the observed phenotype frequencies in 3459 samples tested with anti-A, anti-B and $a_{1}$, by Ikin, Prior, Race and Taylor (1939). The MNS calculations are based on the observed phenotype frequencies in the collected figures of the first three groups of workers given in table 6 . The $\mathrm{Rh}$ calculations are based on the observed frequencies of the phenotypes in 1073 samples of blood tested with anti-D, - G, -c, - $\mathrm{C}^{\mathrm{w}}$, -E and -e (Race, Mourant, Sanger and Lawler, I948).

TABLE 6

The frequency of the 6 phenotypes of the MNS system

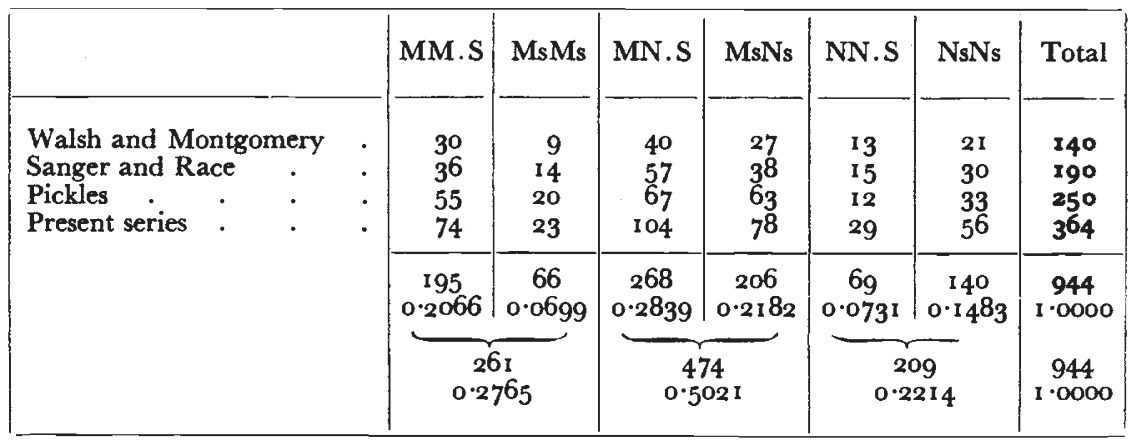

Since the publication of our original tests on 190 unrelated persons we have tested a further 364 samples (including most of the parents of the families here described). The results are given in table 6 together with the figures previously published. The 364 were not available when Fisher calculated the gene frequencies which we have used in this paper; their inclusion would not make any material difference to the results.

\section{SUMMARY}

The MNS groups of 93 English families have been determined. The results, combined with those previously published for 30 families, have been examined statistically, and are consistent with the hypothesis that $S$ and $s$ are genes very closely linked to the MN genes. So far 
no recombination has been observed among 82 relevant children. The results are given of testing a further series of 364 unrelated English persons for these groups.

Acknowledgments.-We are most grateful to Dr M. M. Pickles of the Pathological Department, Radcliffe Infirmary, Oxford, who discovered the second example of anti-S serum and gave us a most generous supply.

We also wish to thank the members of the families for allowing us to take samples of their blood.

\section{REFERENCES}

IKIN, ElizABETh W., PRIOR, AILEEN M., RACE, R. R., AND TAYLOR, G. L. I 939 . The distributions in the $\mathrm{A}_{1} \mathrm{~A}_{2} \mathrm{~B} \mathrm{O}$ blood groups in England.

Ann. Eugen., Lond., 9, 409.

PICKLES, MARGARET M. I $94^{8}$.

A further example of the anti-S agglutinin.

Nature, $162,66$.

RACE, R. R., MOURANT, A. E., LAWLER, SYLVIA D., AND SANGER, RUTH. $194^{8}$. The $\mathrm{Rh}$ chromosome frequencies in England.

Blood, 3, 689.

SANGER, RUTH, AND RACE, R. R. I947.

Subdivisions of the MN blood groups in man.

Nature, 160,505 .

SANGER, RUTH, RACE, R. R., WALSH, R. J., AND MONTGOMERY, GARMEL. 1948. An antibody which subdivides the human MN blood groups.

Heredity, 2, 131 .

WALSH, R. J., AND MONTGOMERY, CARMEL. 1947.

A new human iso-agglutinin subdividing the $\mathrm{MN}$ blood groups.

Nature, $160,504$. 